\title{
Customer Satisfaction on Banking Channels
}

\author{
Gokul Prasad ${ }^{1}$ \\ Anuradha Arthanar ${ }^{2}$ \\ ${ }^{1+2}$ VIT Business School, VIT University, India \\ Correspondence: Gokul Prasad,VIT Business School, VIT University, India, E-mail: \\ gokulprasad.k2016@vitstudent.ac.in
}

Received: September 12, 2017

Accepted: September 21, 2017

Online Published: September 27, 2017

\begin{abstract}
Satisfaction with banking services is an area of growing interest to researchers and managers. This research examined the survey responses of 120 bank customers who provided information regarding their satisfaction towards financial distribution channels with respect to their banks. The study found that there were distinctive segments within the financial market that had significantly different levels of usage of financial distribution channels. Financial customers' satisfaction with Mobile banking, automated teller machines, credit cards, debit cards, internet banking was investigated, and this information was used to determine if relationships exist between customer satisfaction and the usage of financial distribution channels. Systematic methodology, including design and validation of questionnaire and factor analysis were used to enhance the reliability of the findings. Further results and implications of the study for financial services are addressed.
\end{abstract}

Keywords: Bank Services, Customer Orientation, Customer Satisfaction, Financial Distribution Channels, Indian Banks, Internet Banking.

\section{Introduction}

The banking industry, integral to our commercial and personal lives, has evolved with the times to embrace new challenges and cater to constantly changing consumer behaviour and attitudes. Technology has undoubtedly played an obvious and increasingly important role in the evolution of the banking industry towards digitization. This shift to e-banking or digitization brings with it security threats and strong competition. Banks are increasingly seeing the need to implement, and have started putting in place, new services that benefit both themselves in terms of maintaining profitability, as well as customers by way of providing a better and more convenient experience. In the Middle East, the UAE has been an early adopter of digital technology, resulting in a phase of rapid mass digital transformation in many sectors, including banking.

Rising numbers of financial institutions are introducing and expanding their offerings of electronic banking products. Banks have augmented their distribution networks with transactional websites, which allow customers to open accounts, apply for loans, check balances, transfer funds, and make and receive payment over the internet. Some institutions view internet banking as a way to lower costs or to create new revenue streams by attracting additional customers and selling more services to current customers. Other 
institutions have begun to offer internet-banking services/e-services as a defensive step, out of concern that current customers may switch to another financial institution with more advanced electronic banking services. However, diffusion and adoption of electronic banking axis expected to progress rapidly.

With the emergence of e-commerce, the way in which banking business is presently conducted will undergo a radical change. Future competition among banks will be essentially basedon the twin platforms of technology savviness and ability to attract talent. Mobile and internet banking will gain in importance and the future will see the emergence of social networking driven transactions.Increasing competition willexert pressure on bottom lines, forcing banks to cope with thinning margins.The UAE banking sector is heading for consolidation. The presence of many regional players will see few banks emerging as global competitors. Clearly, services have been the key driver in economic momentum of the country.This change has put responsibility on policy makers to see that bank customer's are satisfied with their services. This research paper is an endeavor towards judging the satisfaction of the customer and their relationship with banks under study. It is the duty of the banks to ensure satisfied customers, which also leads to an increase in the profitability of the banks.Financial institutions are starting to perceive distribution to be a competitive weaponas the numbers of alternative strategies by which a financial institution can competitively differentiate itself are disappearing (Friars et al., 1985, in Easingwood and Storey, 1996).With the introduction of new delivery channels, such as mobile and internet banking,many financial institutions are viewing distribution channels as an opportunity for differentiating themselves in the market.

Developing alternative distribution channels is important, not only in terms of reducing costs and improving competitiveness, but also in terms of a financial institution's ability to retain the existing customer base (Kimball and Gregor, 1995) and to attract new customers. A major factor of consideration when determining a financial distribution strategy is consumer preferences. Soldatos (1995) proposes that consumers, and not service providers, choose the appropriate distribution channel and place of delivery.Similarly Lovelock (1991) states that a firm's delivery system needs to be consistent with the target market's preferences. This study looks at customers' satisfaction with the usage of financial distribution channels to determine if there are particular attitudinal segments of customers who exhibit similar patterns of access to financial services. This should enable financial institutions to more effectively and efficiently manage and market their delivery of financial services.

\section{Background}

In the past, the branch network of a financial institution was the main competitive weapon used to protect market share and profits. However, the current market environment allows new competitors to emerge and different methods for accessing a financial institution's services have been developed. Additionally, deregulation has seen the market entry of financial service providers who offer mortgage products and do not have the cost burden of a large branch network. Such providers are placing even more pressure on existing financial institutions to find other avenues for revenue or profit growth(Howcroft, 1993). Competition within the financial industry has forced many of the players in the market to offer similar prices on deposits and loans. This competitive environment is likely to intensify in future years, particularly when considering the trends of rapid technological change and globalisation of financial markets (Brown, 1992). The implications of this for financial institutions are that it is of increasing importance that new, non-price factors be found which can be used as a means of differentiation, to achieve higher revenue growth and improved market share.Financial institutions are also looking at ways of cutting costs. It is widely recognized that one of the largest expenses 
incurred by financial institutions is the branch networkand its associated staff and overhead costs. It is, therefore, understandable that financial institutions are currently reviewing the way in which their customers are able to access their money from the institution (Devlin, 1995; Howcroft, 1993; Wood, 1997). A furthermeans by which financial institutions are attempting to differentiate themselves is throughan improved use of financial services marketing. The traditional 'tangibilising' powers of bank branches continue to be of importance within financial services marketing (Greenland, 1995). However the extent of the branchnetwork's advantage, in terms of tangibility, is diminishing as new financial institutions,can effectively compete within the market without requiring the tangible cue of a branch(Ennew, 1997).

\section{Literature Review}

Author/s Distribution channel/s Data gathering No. of responses/ Additional information studied instrument country Swinyard and ATMs Self-administered 183/Singapore Random systematic sample

Ghee (1985) questionnaire factor analysis/discriminant analysis/chi-square/t-tests

Moutinho and Meidan (1989) New technology Interviews 200/UK Stratified sample/effect of ageand gender studies 14 attitudinal statements towards banking,

7-point scale Marr and Prendergast (1993) Human tellers and ATMs Mail survey 803/New Zealand Factor analysis used Random sample/customers who were card holders

Le Blanc (1990) ATMs Mail survey 208/Canada Systematic random sample/Credit union customers/40 attitudinal statements,7-point Likert scale(agree disagree)

Prendergast (1993) ATMs/EFTPOS/ Telephone interviews 302/New Zealand Random sample/chi-square Telephone banking analysis used

Iversen and Rugimbana (1994) ATMs Branch-floor intercept 630/Australia Convenience sample Bank questionnaire and credit union customers' sampled/5-point Likert scale/14 statements

Rugimbana (1995) ATMs Branch-floor intercepts 430/Australia Convenience sample/Likertquestionnaire scale -14 questions/factoranalys is and regression

Barczak et al. (1997) ATMs, telephone Mail survey/USA 331 Factor analysisbanking, debit cards

\section{Objectives of the Research}

The purpose of this study is to investigate whether the satisfaction of the customer is different with the current usage levels of ATMs, debit cards, credit cards, internet banking/mobile banking and telephone banking with different banks.

\section{Research Methodology}

The research instrument consisted of a structured questionnaire and the respondents' were required to indicate their responses with the help of the interviewer. The questionnaire survey has been widely acknowledged as an efficient tool for assessing the perceptions of individuals/organizations on a particular subject. Pilot testing of the measurement instrument was necessary to validate the items and the whole scale. This is because some of the measurement items were developed or modified for the purposes of this researchand because the questions in the instrument were newly compiled to form a new questionnaire. The pilot testing was conducted in a series of steps. Before the final surveyinstrument was set up, a preliminary questionnaire was developed and tested to validate the scale items to be used in the study. The banking sector has been chosen because satisfaction with service plays a significant role in high involvement (high interaction between the customers and service providers) industries like banks. In this context,customer satisfaction could be identified as a composite of overall attitudes that customers have towards the bank financial distribution system. The questionnaire was modified where necessary, 
to suit the context of UAE Banking.

Each item employed a seven point Semantic Differential scale, fully anchored by extremely satisfied (1) at one end to extremely dissatisfied (7) at the other. Additional dataon demographics were also collected.Data were collected by means of a questionnaire administered to the customers of the five banks chosen for present research.

The banks chosen for the present research were Ajman Bank, Sharjah Islamic Bank, National Bank of Umm al qaiwain, Noor Bank. These banks were chosen because these banks are upcoming banks who wanted to bring about the revolutionary changes into the channels. These banks have astrong retail presence and offer a comprehensive range of information to the customer.There were no leading or misleading questions used in the questionnaire. The questionnaire was an on-disguisedone. This would bring objectivity in the analysis.Secondly, in order to get a representative heterogeneous sample of respondents it was decided to collect data from four different places in the country. Thirdly, the questionnaire was administered only to those customers who had been with the bank for at least three years. This was done to judge the effect of satisfaction. These steps hopefully may reduce the respondent's bias, if any, largely.The sample of respondents was chosen using probability sampling.With in probability, and systematic sampling was used. From the entire banks, we acquired a list of 200 customers who had been with the bank for at least three years. Out of 200, we could get appointments with 120 customers. Although cooperation was generally good, there were some refusals to participate in the study due to time pressure on the part of respondents and hesitation on the part of the individual to part with information. The researcher personally filled up the questionnaire for every respondent.Out of 120 customers contacted we got 90 (75\%) completed questionnaires.

\section{Development of Hypotheses \& Data Anlaysis}

Due to the numerous combinations of the types of customers from different banks and types of distribution channels that will be tested in this study the expected relationships are presented in summary form, as detailed below.

Summary of Hypothesis

$\mathrm{H}_{1}$ There is no significant difference in satisfaction of the customer with ATM usage of different banks

$\mathrm{H}_{2}$ There is no significant difference in satisfaction of the customer with credit cards of different banks

$\mathrm{H}_{3}$ There is no significant difference in satisfaction of the customer with debit cards of different banks

$\mathrm{H}_{4}$ There is no significant difference in satisfaction of the customer with mobile banking of different banks

$\mathrm{H}_{5}$ There is no significant difference in satisfaction of the customer with internet banking of different banks

The hypotheses stated above, that there is no difference in satisfaction levels ofthe customer with different financial distribution channels is proved unacceptable by the $\mathrm{f}$ test, proving that there is a significant difference in the satisfaction of the customer with various services, namely the ATM, Debit card, Credit card, teller, mobile banking and Internet banking.

\section{Difference in satisfaction with current usage of distribution channels in banks}

\begin{tabular}{lllllll}
\hline \multicolumn{7}{l}{ Type of Financial distribution channel } \\
\hline \multicolumn{1}{l}{ ATM } & Debit Card & Credit Card & Mobile Banking & Internet Banking & Teller \\
\hline \begin{tabular}{l} 
F-Ratio \\
\hline
\end{tabular} & $4560=7.516$ & $4560=13.26$ & $4560=11.06$ & $4560=2.45$ & $4560=4.82$ & $4560=13.85$ \\
\hline & & & & & \\
\hline
\end{tabular}


The demographic information of the customers of banks is shown below. The sample size of this research consisted of $70 \%$ males and $30 \%$ females. $51 \%$ are married and $48 \%$ unmarried. The remaining categories were insignificant.

Demographic profile of the respondents

Demographics

1. Gender

Male $-70 \%$

Female 30\%

2. Marital status

Married $50 \%$

Unmarried 50\%

3. Monthly Family Income

Less than AED.100018\%

AED.1000-AED. 5000 30\%

AED.5000-AED. 10,000 31\%

AED.10, 000-AED. 20,000 13\%

More than AED. 20,000 8\%

4. Age

Less than 25 years $32.8 \%$

25-35 years $27.0 \%$

$35-45$ years $23.8 \%$

45-55 years $11.9 \%$

More than 55 4.5\%

5. Education

a. Secondary $1.3 \%$

b. Higher secondary $2.7 \%$

c. Undergraduate $3.4 \%$

d. Graduate $40.9 \%$

e. Post Graduate $51.7 \%$

6. Occupation

a. Home maker $4.9 \%$

b. Service $45.6 \%$

c. Self employed $25.2 \%$

d. Retired $1.6 \%$

e. Students $22.7 \%$ 
The results from the below shows the satisfaction of the customer with various services

\begin{tabular}{|c|c|c|c|c|c|c|}
\hline Name of the bank & Ajman Bank & Noor Bank & $\begin{array}{l}\text { National Bank } \\
\text { of Umm Al } \\
\text { Qaiwain(NBQ) }\end{array}$ & $\begin{array}{l}\text { National Bank } \\
\text { of } \\
\text { Fujairah(NBF) }\end{array}$ & $\begin{array}{l}\text { Sharjah } \\
\text { Islamic } \\
\text { (SIB) }\end{array}$ & Bank \\
\hline
\end{tabular}

\begin{tabular}{llllll}
\hline Services & \multicolumn{1}{l}{} & & \\
\hline ATM & 3.303 & 2.3984 & 2.2361 & 2.5294 & 2.8889 \\
\hline Debit Card & 2.6768 & 3.5447 & 2.1806 & 2.9176 & 3.0988 \\
\hline Credit Card & 2.6465 & 3.5366 & 2.3889 & 3.0647 & 2.8642 \\
\hline Mobile Banking & 3.0909 & 3.6179 & 2.8111 & 3.2941 & 3.5432 \\
\hline Internet Banking & 3.2424 & 3.6179 & 2.7917 & 3.2706 & 3.6543 \\
\hline Teller & 2.6061 & 3.8049 & 2.8611 & 3.0412 & 3.7284 \\
\hline
\end{tabular}

Notes: The results from the table are as follows:

Satisfaction with ATM is most with NBQ and least with Ajman Bank.

Satisfaction with Debit card is most with NBQ and least with SIB.

Satisfaction with Credit card is most with NBQ and least with Noor Bank.

Satisfaction with Mobile Banking is most with NBQ and least with Noor Bank.

Satisfaction with Internet banking is most with Ajman Bank and least with Noor Bank.

\section{Conclusion}

The research from the study reveals that customer's satisfaction with banks distribution channels is different for the banks taken for study. Thus, we reject the various Null Hypotheses in the study. Thus financial service marketing needs to think in terms of distribution mixes, rather than focusing upon one dominant channel. However, a financial institution could benefit from specializing in the delivery of particular groupings of distributing channels. Alternatively if the financial institution wishes to attract or retain convenience, technology oriented customers they may find that greatly reducing their relatively expensive branch network and increasing availability and accessibility of more self-service distribution channels may improve customer satisfaction and the institution's bottom line. The study also suggests that the satisfaction of the customer is greater with private banks rather than nationalized banks. Thus, the banks in UAE have to gear up to be more competitive in serving the customer through various distribution channels.

Looking at the demographic profile of the respondents, the customers who are less than 35 years of age are more satisfied with the bank's distribution channels, thus thebank has to come up with a strategy to satisfy the customers above 35 years of age.The study was conducted within a limited geographical area.Cost and time limitations also had an impact on the type of data collection instrument that was used in the study. Potential biases also exist using a mile-out questionnaire due to refusals to participate in the study and respondent non-cooperation (Jarboe, 1993). Other attitudinal factors, which were not included in this study, could be explored in an attempt to explain the motivations behind the current and future usage of financial distribution channels.

A replication of this study in a different geographical region is a means for confirming the level of representativeness of this study. Additionally it may be interesting to conduct a similar study inother markets, to determine if the findings of the study can be applied to other market environments. Additionally, the 
findings of this study will need to be updated regularly to keep pace with the changes occurring within the banking industry, particularly in regard to the potential introduction of new distribution channels such a smart cards, or the spread ofexisting distribution channels, such as internet banking.

\section{Marketing Implications}

Distribution as a means for differentiation and a corporate responsibility issue financial distribution channels are capable of providing an opportunity for differentiation by offering delivery services to customers in ways that are unique and valued by customers.Furthermore, Devlin (1995) believes that a financial institution's distribution mix, such as the appropriate mix of branches, ATMs and telephone banking, rather than its products,such as saving and loan rates, could be used to differentiate itself in the banking industry.

It is responsibility of the banks to ensure that the right mix of distribution channels is provided to the customer so that he is satisfied.This study provides insight into the satisfaction of the customer with the banking industry's different financial distribution channels.

\section{References}

Barczak G., Ellen, P. and Pilling, B. (1997), 'Developing typologies of consumer motives for use of technologically based baking services', Journal of Business Research.

Bauer, J. (1995) 'The dynamics of segmentation strategy', Financial Services International, Vol. 7, December

Brown, L. (1992) Competitive Marketing Strategy, Australia: McArthur Press.

Devlin, J. (1995) 'Technology and innovation in retail banking distribution', International Journal of Bank Marketing.

Easingwood, C. and Storey, C. (1996) 'The value of multi-distribution systems in the financialservices sector', Service Industries Journal,

Ennew, C. (1997) 'Developing marketing strategy', in C. Ennew, T. Watkins, and M. Wright(1995) Marketing Financial Services, 2nd ed., UK: Butterworth Heinemann,

Howcroft, J.B. (1993) 'Branch networks and alternative distribution channels: threats and opportunities', International Journal of Bank Marketing.

Iversen, P. and Rugimbana, R. (1994) 'Perceived attributes of ATMs and their marketingimplications', International Journal of Bank Marketing.

Jarboe (1993) The Marketing Research Project Manual, 2nd edition, New York, NY: West Publishing Co.

Kimball, R. and Gregor, W. (1995) 'How distribution is transforming retail banking: changesleading banks are making', Journal of Retail Banking Services.

Leblanc, G. (1990) 'Customer motivations: use and non-use of automated banking', International Journal of Bank Marketing.

Lovelock, C. (1991) Services Marketing, 2nd ed., Englewood Cliffs: NJ: Prentice-Hall.

Marr, N. and Prendergast, G. (1993) 'Consumer adoption of self-service technologies in retailbanking: is expert opinion supported by consumer research?', International Journal of Bank Marketing.

Mercer, D. (1995) 'Future directions in banking - the changing nature of financial services', The Australian Banker,

Moutinho, L. and Meidan, A. (1989) 'Bank customers' perceptions, innovations, and newtechnology', International Journal of Bank Marketing. 
Prendergast, G. (1993) 'Self-service technologies in retail banking: current and expected adoption patterns', International Journal of Bank Marketing.

Rugimbana, R. (1995) 'Predicting ATM usage: the relative importance of perceptual anddemographic factors', International Journal of Bank Marketing.

Soldatos, J. (1995) 'Future trends in marketing bank services', The Australian Banker, August,

Swinyard, W. and Ghee, L. (1985) 'Adoption patterns of new banking technology in SoutheastAsia', International Journal of Bank Marketing.

Wood, C. (1997) 'Betting on the bank on an electronic future', Business Review Weekly, February24.

Bibliography

Athanassopoulou, P. and Johne, A.C. (2004) 'Effective communication with lead customers indeveloping new banking products', International Journal of Bank Marketing, 22( 2).

CUSCAL (1997) Credit Union Services Corporation Australia Limited Membership Information,Sydney.

(COFC) Council on Financial Competition (1995) The Journey Begins - Migration Beyond Branch Dependence, Washington, USA: The Advisory Board Company.

Friars, E. (1985) 'Applying retailing principles in retail banking', Journal of Retail Banking,7(3).

Greenland, S. (1995) 'Network management and the branch distribution channel', International Journal of Bank Marketing, 13(1).

Howcroft, B. and Keily, J. (1997) 'Distribution channels', in C. Ennew, T. Watkins and M. Wright(1995) Marketing Financial Services, 2nd ed., Oxford: Butterworth Heinemann

Irons, K. (1997) The Marketing of Services, Maidenhead: McGraw Hill Publishers.

Jayachandran, S., Hewett, K. and Kaufman, P. (2004) 'Customer response capability in asense-and-respond era: the role of customer knowledge process', Journal of the Academy of Marketing Science, 32(1).

Karjaluoto, H., Mattila, M. and Pento, T. (2002) 'Factors underlying attitude formation towardsonline banking in Finland', International Journal of Bank Marketing,

Kolodinsky, J.M., Hogarth, J.M. and Hilgert, M.A. (2004) 'The adoption of electronic bankingtechnologies by US consumers', International Journal of Bank Marketing.

Lenskold, J.D. (2004) 'Customer-centric marketing ROI', Marketing Management,

Llewellyn, D. and Drake, L. (1997) 'Pricing', in C. Ennew, T. Watkins and M. Wright (1995)Marketing Financial Services, 2nd ed., Oxford: Butterworth Heinemann

McDougall, G. and Levesque, G. (1994) 'Benefit segmentation using service quality dimensions:an investigation in retail banking', International Journal of Bank Marketing, 12(1).

Seigbert, P., Stitt, G. and Weber, M. (1996) 'Competitive convenience. Redefining branchingis part of a comprehensive approach to strategic delivery system planning', Credit Union Management.

Sraeel, H. (1996) 'Customer interaction defines the new banking age', Bank Systems and Technology, 33(1).

\section{Copyrights}

Copyright for this article is retained by the author(s), with first publication rights granted to the journal. 